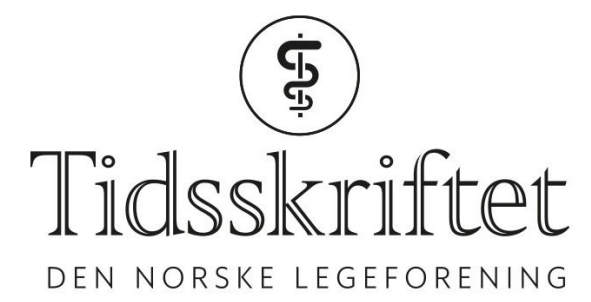

\title{
Effekten av vedlikeholdsmedisinering med antipsykotika
}

KOMMENTAR

WALTER KEIM

E-post: walter.keim@gmail.com

Walter Keim er pensjonist og tidligere høyskolelektor ved Høgskolen i Sør-Trøndelag, Trondheim. Ingen oppgitte interessekonflikter.

I artikkelen Medisinfrie sykehusposter - et kunnskapsløst tiltak i Tidsskriftet nr. 6/2017 omtaler Røssberg og medarbeidere effektiviteten av antipsykotiske midler som at hos "det store flertallet bidrar medisiner til symptomlette, funksjonsbedring og høyere selvrapportert livskvalitet” (1). Hvor stort er dette flertallet? Ifølge Leucht og medarbeideres metaanalyse er det $18 \%$, det betyr at antall pasienter som må behandles for at én ekstra pasient skal oppnå bedring, er seks (NNT = number need to treat) (2). Med henvisning til Wunderink og medarbeideres toårsstudie konkluderer Røssberg og medarbeidere at "hvor lenge den medikamentelle behandlingen bør foregå, er fortsatt forskningsmessig uavklart”. Kanskje kan Wunderink og medarbeideres syvårsoppfølgingsstudie gi svar (3)? Her var etter seks måneders stabilisering kontrollgruppen uten medisinering. Etter syv år oppnår ca. 40 \% tilfriskning (recovery) uten og ca. 18 \% med antipsykotika.

Harrow \& Jobes langtidsfors $\emptyset \mathrm{k}$ viser at pasienter med schizofreni underlagt medikamentredusert behandling klarer seg bedre i det lange løp, dvs. 50 \% ble vesentlig bedre (høyere tilfriskning) etter 15 år sammenlignet med de $5 \%$ som var langtidsmedisinerte (4). Studien er blitt kritisert fordi utvalget ikke er randomisert. Imidlertid har Wunderink og medarbeideres randomiserte studie replikert resultatene. Vekt på tilfriskning er i ferd med å bli det normale, og ledende forskere er enig i at høye doser med vedlikeholdsmedisinering svekker tilfriskningen. Det som blir beskrevet som "effektivt for det store flertallet", gavner bare et mindretall på kort sikt og viser seg å svekke muligheten for tilfriskning på lengre sikt. Wunderink og medarbeidere uttaler også at antipsykotika ikke reduserer, men bare utsetter symptomene når man ser på et mangeårig tidsrom (5). De nasjonale retningslinjene om psykosebehandling trenger oppdatering.

Jeg har derfor skrevet et åpent brev til Helsedirektoratet, Kunnskapssenteret, Folkehelseinstituttet, Legemiddelverket og Pasientsikkerhetsprogrammet om kunnskapsog forskningsbasert avvikling av nåværende helseskadelige overmedisinering i psykiatrien til fordel for kunnskapsbasert helsefremmende praksis (6). Etter min mening må det bli et valg basert på informert samtykke om pasientene foretrekker symptomlindring i akutte faser på bekostning av svekkede tilfriskningsmuligheter i et lengre tidsperspektiv. 
1. Røssberg JI, Andreassen OA, Ilner SO. Medisinfrie sykehusposter - et kunnskapsløst tiltak. Tidsskr Nor Legeforen 2017; 137: 426 - 7. [PubMed][CrossRef]

2. Leucht S, Tardy M, Komossa K et al. Maintenance treatment with antipsychotic drugs for schizophrenia. Cochrane Database Syst Rev 2012; 5 CDoo8016. [PubMed][CrossRef]

3. Wunderink L, Nieboer RM, Wiersma D et al. Recovery in remitted first-episode psychosis at 7 years of follow-up of an early dose reduction/discontinuation or maintenance treatment strategy: long-term follow-up of a 2-year randomized clinical trial. JAMA Psychiatry 2013; 70: 913 - 20. [PubMed][CrossRef]

4. Harrow M, Jobe TH. Factors involved in outcome and recovery in schizophrenia patients not on antipsychotic medications: a 15-year multifollow-up study. J Nerv Ment Dis 2007; 195: 406 - 14. [PubMed]

5. 2015 Yale Symposium - Lex Wunderink, MD, PhD. Publisert 31. juli 2015. https://www.youtube.com/watch?vRKeBjLG-ueY (22.5.2017).

6. Åpent brev til Helsedirektoratet, Kunnskapssenteret, Folkehelseinstituttet, Legemiddelverket, Pasientsikkerhetsprogrammet 12.2.2017: Kunnskaps- og forskningsbasert avvikling av nåværende helseskadelige overmedisinering i psykiatrien til fordel for evidensbasert helsefremmende praksis. http://home.broadpark.no/ wkeim/files/Aapent_brev_kunnskap-uv.html (22.5.2017).

Publisert: 21. august 2017. Tidsskr Nor Legeforen. DOI: 10.4045/tidsskr.17.0469

(C) Tidsskrift for Den norske legeforening 2020. Lastet ned fra tidsskriftet.no 